\title{
Effect of Vegetation Time and Climatic Conditions on trans- Resveratrol Concentrations in Cabernet Sauvignon and Merlot Wines from Different Regions in Turkey
}

\author{
Ü.R. Yaman ${ }^{1 *}$, B.Ç. Adıgüzel ${ }^{1}$, U. Yücel ${ }^{1}$, N. Çetinkaya ${ }^{2}$ \\ (1) Food Technology Programme, Ege Vocational School, Ege University, 35040 İzmir, Turkey \\ (2) Department of Plant Protection, Ege University Faculty of Agriculture, 35040 İzmir, Turkey
}

Submitted for publication: February 2016

Accepted for publication: April 2016

Key words: Geographical origins, climatic conditions, resveratrol, Turkish wine

\begin{abstract}
In this study, 21 wine samples obtained from wine manufacturers in Turkey and produced from different grape varieties cultivated in different geographical regions, were analysed to determine their resveratrol concentrations. The HPLC method was used to analyse the trans-resveratrol concentrations of wines. Statistical analysis was done using IBM SPSS Statistics Version 20.0.0. Mean values were compared by using the Tukey test at a confidence level of $p=0.05$. The resveratrol concentrations of Cabernet Sauvignon and Merlot grapes were also determined. Since these two varieties are grown widely in many regions of Turkey, they were studied in terms of the relationship of the resveratrol concentrations with parameters such as time of vegetation, total effective temperature, sunshine duration and rainfall. Positive correlations were observed between resveratrol levels and grape varieties, geographical regions and total effective temperature. The results of the statistical analysis showed that resveratrol concentrations also varied depending on vegetation time, sunshine duration and amount of rainfall in the vineyards. This study aimed to identify the relationships between (1) resveratrol concentrations of wines, (2) vegetation time of the grapes and (3) climatic conditions of the respective regions. Moreover, the effects of grape types on resveratrol concentrations were investigated. This study contributes to the body of knowledge by providing results on the utilisation of grapes that have high resveratrol levels for producing wines that have functional properties that are increasingly in demand by consumers.
\end{abstract}

\section{INTRODUCTION}

Wine contains high concentrations of polyphenolic compounds that are known to have protective properties against coronary heard diseases, cancer and inflammation. In vitro and in vivo investigations show that especially red wine has preventive effects against leukaemia, skin, lung and prostate cancers. Recent findings from in vivo investigations point out that trans-resveratrol is an effective agent during the initial, development and progressive phases of cancer (Bravo et al., 2006; Anl1 et al., 2006; Stervbo et al., 2007; Cottart et al., 2010; Schaffer et al., 2012; Singh et al., 2015; Zielińska et al., 2015).

Trans-resveratrol, a type of polyphenolic component of red wine, is produced in grape skins in reaction to biotic and abiotic stress in vineyards (Cui et al., 2002; İkizler et al., 2003; Olson et al., 2005; Cottart et al., 2010). Fungal infections are an example of biotic stress, whereas ultraviolet (UV) light exposure and climatic conditions are examples of abiotic stress. The effects of sunshine duration and UV light exposure on the resveratrol concentrations of red wines were investigated separately and were found to increase resveratrol concentrations to a considerable extent (Threlfall et al., 1999).
In many studies, several methods have been used to determine resveratrol concentrations. Several wines that were produced from different types of grapes and in different geographical locations have been analysed, and the results have been evaluated by researchers using comparable methods. The trans-resveratrol concentrations of 42 Hungarian wines from two different locations and producers were determined by Montsko et al. (2010). In another study, 12 red wines from commercial producers and three locations in Croatia were analysed to measure the polyphenolic concentrations, and then correlations between geographical conditions, such as the soil properties of the vineyard, sunlight exposure and temperature, and the resveratrol concentrations of the wines were investigated (Rastija et al., 2009). The trans-resveratrol concentrations of 186 Portuguese red wines from different grape types, origins and vintages were analysed (Paulo et al., 2011). Another study (Adigüzel et al., 2010), on the relationship between geographical origin and climatic conditions of grapes, determined resveratrol concentrations. The highest resveratrol concentrations were found in red wine produced from the Öküzgözü black grape

*Corresponding author: E-mail address: unalrizayaman@gmail.com [Tel.: +90-232-3111460, Fax: +90-232-3887599] 
type from East Anatolia. The content of resveratrol and some related stilbenes in 21 Italian red grape varieties growing in the same edaphoclimatic conditions and at the same stage of ripeness were measured in another study. Some varieties, like Barbera, Schiava gentile, Corvina and Marzemino, showed a resveratrol content in the skin two to three times higher than the average concentration of all varieties. Considering the total concentrations of stilbenes, the highest content was found in Barbera, Franconia, Negroammaro, Corvina and Marzemino, whereas the other varieties, such as Montepulciano, Dolcetto, Croatina, Refosco and Primitivo, synthesised these phenolics in very low concentrations. Barbera grapes could be an interesting variety as a source of health-promoting molecules because relatively high concentrations of trans-piceatannol were analysed in this grape (Vincenzi et al., 2013).

The main aim of this research was to investigate the relationship between the resveratrol concentrations of red wines from different geographical and climatic conditions. It is known that resveratrol is a polyphenolic compound that has very important protective properties against coronary heart diseases, many cancer types, Alzheimer and inflammatory diseases. This polyphenolic compound is synthesised in the skin of grapes when the plant is under specific stress conditions, such as fungal infections, drought, insufficient sunlight exposure and insufficient temperature. In this study, the changes in resveratrol concentrations of wines with all these parameters were analysed using the HPLC method and the results were examined statistically. The reasons for the differences are presented and the correlations that influenced these differences are discussed.

\section{MATERIALS AND METHODS \\ Materials}

A total of 21 wines that had been produced from different grape varieties (Cabernet Sauvignon, Syrah, Merlot, Granache, Alicante, Cinsault, Öküzgözü, Boğazkere, Kalecik Karası and Çalkarası) cultivated in different geographical locations (Denizli, Çanakkale, Tekirdağ, Bozcaada, İzmir, Ankara, and Elazı ğ) were obtained from Turkish wineries. In this study, Cabernet Sauvignon (Vitis vinifera L.) and Merlot (Vitis vinifera) black grapes grown in Elazı̆̆ and Denizli were used.

Trans-resveratrol (Catalogue number: R5010) standardly used in calibration was purchased from Sigma (St. Louis, MO, USA). Methanol and acetonitrile solvents (HPLC grade) were purchased from Carlo Erba (Darmstadt, Germany).

\section{Determination of resveratrol concentrations}

For the quantitative analyses of the resveratrol concentrations of the wine samples, a Shimadzu (Tokyo, Japan) SCL-10 A VP HPLC instrument consisting of a UV-VIS detector (SPD-10A VP) was used. The system includes an LC-10 AT Liquid Chromatography (LC) pump (quaternary gradient) and degasser (DGU-14A) units. The column used was LiChrospher RP $5 \mu \mathrm{m}$ (250 X 4 mm I.D.). Wine samples $(20 \mu \mathrm{L})$ and calibration standards were injected directly into the column. For trans-resveratrol elution, distilled water (pump A) and acetonitrile solvent (pump B) were used as the mobile phase in a ratio of 65:35 and at a flow rate of $1 \mathrm{~mm} /$ min. Wine samples were analysed with a UV-VIS detector at $289 \mathrm{~nm}$ wavelength (Denzer, 1991). Chromatographic peaks were determined according to retention times. The retention time of trans-resveratrol was $6.5 \mathrm{~min}$ for the analysis conditions. Triplicate measurements were performed for all wine samples. Stock solution was prepared by using $0.0005 \mathrm{~g}$ trans-resveratrol $/ 10 \mathrm{~mL}$ methanol. Calibration solutions were prepared from this stock solution in the range of 0 to $10 \mathrm{mg} / \mathrm{L}$. Resveratrol concentrations were obtained as milligrams per litre from a standard curve formula.

Resveratrol concentrations of the wine samples were compared with respect to their geographical origins, vegetation time (VT, in days), which refers to the ripeness of the grapes, total effective temperature (TET, in ${ }^{\circ} \mathrm{C}$ ), which means the total temperature during the maturation process, sunshine duration ( $\mathrm{SD}$, in $\mathrm{h}$ ), and rainfall (RF, in $\mathrm{kg} / \mathrm{m}^{2}$ ).

\section{Statistical analysis}

Statistical analysis was done using the IBM SPSS Statistics Version 20.0.0 program. Mean values were compared by Tukey test at a confidence level of $p=0.05$. The relationships between the parameters were determined by Pearson coefficient.

\section{RESULTS AND DISCUSSION}

In this study, a survey was conducted to determine the resveratrol values of red wines provided from different regions of Turkey. The resveratrol concentrations were obtained as a result of analysing different wines that were produced using the same vinification process in four different regions of Turkey: the Aegean, Central Anatolia, East Anatolia and Thrace. The different climatic conditions in the regions where the grapes were grown and the vegetation times of the vineyards were compared (Table 1).

Table 1 shows that the highest resveratrol concentration $(2.59 \mathrm{mg} / \mathrm{L})$ was obtained from the wines produced from Öküzgözü black grapes grown in Elazığ. This finding is in correlation with the study done by Adigüzel et al. (2009), who determined the concentration of resveratrol in Turkish wines. They reported the highest resveratrol concentration as $6.47 \mathrm{mg} / \mathrm{L}$ from wine obtained from Öküzgözü black grapes that were grown in East Anatolia, whereas the range of resveratrol levels in the other wines varied between 0.15 and $4.04 \mathrm{mg} / \mathrm{L}$. Similarly, in another study, the highest resveratrol concentration detected in wine was $4.403 \mathrm{mg} / \mathrm{L}$, also obtained from Öküzgözü grapes, whereas the ranges for the other red wines were 0.176 to $4.403 \mathrm{mg} / \mathrm{L}$ (Gürbüz et al., 2007).

The results show that high values of resveratrol concentration were found in wines produced from Öküzgözü and Kalecik Karası grapes. These cultivars are native varieties of Eastern Anatolia and Central Anatolia respectively. Moreover, when the climatic conditions of the regions where the grapes were grown were considered, the vegetation time of the Öküzgözü grape was 122 days, while it was 93 days for the Kalecik Karas1. The total effective temperature was similar for both types of grapes, Cabernet Sauvignon and Merlot, while sunshine duration was slightly longer in the Elazığ region, but rainfall was much lower than in the Denizli 
TABLE 1

Resveratrol concentrations according to regions and grape varieties.

\begin{tabular}{|c|c|c|c|c|c|c|c|}
\hline Grape varieties & Region & Abbreviation & $\begin{array}{l}\text { Resveratrol } \\
\text { conc. }(\mathrm{mg} / \mathrm{L})\end{array}$ & $\begin{array}{l}\text { Vegetation } \\
\text { time (days) }\end{array}$ & $\begin{array}{l}\text { Total } \\
\text { effective } \\
\text { temp. }\left({ }^{\circ} \mathrm{C}\right)\end{array}$ & $\begin{array}{l}\text { Sunshine } \\
\text { duration (h) }\end{array}$ & $\begin{array}{l}\text { Rainfall } \\
\left(\mathrm{kg} / \mathrm{m}^{2}\right)\end{array}$ \\
\hline Cabernet Sauvignon & Denizli & CS-D & 0.351 & 97 & 1410 & 1082 & 1692 \\
\hline Öküzgözü & Denizli & O-D & 1.49 & 113 & 1579 & 1232 & 1904 \\
\hline Boğazkere & Denizli & B-D & 0.441 & 126 & 1681 & 1355 & 2075 \\
\hline Kalecik Karası & Denizli & KK-D & 0.312 & 93 & 1363 & 1044 & 1640 \\
\hline Syrah & Denizli & S-D & 0.492 & 84 & 1255 & 960 & 1521 \\
\hline Merlot & Denizli & M-D & 0.403 & 85 & 1268 & 969 & 1534 \\
\hline Çalkarası & Denizli & ÇK-D & 2.28 & 144 & 1765 & 1524 & 2313 \\
\hline Merlot & Çanakkale 1 & M-Ç1 & 1.21 & 112 & 1483 & 1231 & 1863 \\
\hline Merlot & Çanakkale 2 & M-Ç2 & 1.52 & 103 & 1376 & 1151 & 1670 \\
\hline Cabernet Sauvignon & Çanakkale 1 & CS-Ç1 & 0.386 & 130 & 1682 & 1391 & 3352 \\
\hline Merlot & Tekirdağ & M-T & 0.477 & 103 & 1370 & 942 & 2850 \\
\hline Cabernet Sauvignon & Tekirdağ & CS-T & 0.443 & 137 & 1695 & 1170 & 4342 \\
\hline Grenache & Çanakkale 1 & G-Ç1 & 0.569 & 141 & 1784 & 1489 & 3967 \\
\hline Cabernet Sauvignon & Çanakkale 2 & CS-Ç2 & 0.530 & 123 & 1609 & 1329 & 2098 \\
\hline Cabernet Sauvignon & İzmir & CS-İ & 0.319 & 103 & 1624 & 1201 & 866 \\
\hline Alcante & İzmir & A-İ & 0.497 & 98 & 1550 & 1151 & 755 \\
\hline Cinsault & Tekirdağ & $\mathrm{C}-\mathrm{T}$ & 1.42 & 131 & 1647 & 1140 & 3964 \\
\hline Syrah & İzmir & S-İ & 2.08 & 129 & 2199 & 1459 & 1471 \\
\hline Boğazkere & Elazı̆̆ & B-E & 0.601 & 122 & 1875 & 1366 & 1068 \\
\hline Kalecik karası & Ankara & KK-A & 0.371 & 144 & 1533 & 1387 & 3192 \\
\hline Öküzgözü & Elazı ̆̆ & O-E & 2.59 & 122 & 1875 & 1366 & 1068 \\
\hline Cabernet Sauvignon & Denizli & CS-D & 0.351 & 97 & 1410 & 1082 & 1692 \\
\hline Öküzgözü & Denizli & $\mathrm{O}-\mathrm{D}$ & 1.49 & 113 & 1579 & 1232 & 1904 \\
\hline Boğazkere & Denizli & B-D & 0.441 & 126 & 1681 & 1355 & 2075 \\
\hline Kalecik Karası & Denizli & KK-D & 0.312 & 93 & 1363 & 1044 & 1640 \\
\hline
\end{tabular}

region. The negative impact of rainfall on the resveratrol concentration of grapes was consistent with the higher secretion levels of resveratrol under abiotic stress conditions caused by rainfall. Moreover, excessive rainfall is known to increase fungal diseases that may occur in the vineyard. Jeandet et al. (1995) studied the relationship between fungal diseases, especially Botrytis cinerea infection, and the resveratrol concentrations of wine. According to their results, the main factor that determines the concentration of resveratrol in must and wine is the balance between the level of synthesized resveratrol of plants and degraded resveratrol concentration by pathogens. In the results of the abovementioned study, the resveratrol concentration did not increase significantly in the years in which severe Botrytis cinerea infection was seen (the resveratrol concentration was between $0.89 \mathrm{mg} / \mathrm{L}$ and $1.48 \mathrm{mg} / \mathrm{L}$ ), while it was 2 $\mathrm{mg} / \mathrm{L}$ to $2.49 \mathrm{mg} / \mathrm{L}$ when low or moderate fungal infections were observed. In another study, the detected resveratrol concentration of the red wines was between 0.96 and $3.93 \mathrm{mg} / \mathrm{L}$, and the highest value, $3.93 \mathrm{mg} / \mathrm{L}$, was found in the wine produced from black Shiraz grapes (Anli et al., 2006). The resveratrol concentrations of Greek red wine were found to be between 0.38 and $2.14 \mathrm{mg} / \mathrm{L}$ (Gerogiannaki-
Christopoulou et al., 2006)

In this study, significantly different resveratrol concentrations were found even in wines from similar geographical regions, so the interactions were explained by the differences in parameters such as grape variety, vegetation time, total effective temperature, sunshine duration and rainfall. Resveratrol concentrations varied between 0.312 and $2.59 \mathrm{mg} / \mathrm{L}$ and, when grape variety was considered, Öküzgözü had the highest values in both Elazığ and Denizli, followed by the Çalkarası, Shiraz and Cinsault varieties (Fig. 1). Among the varieties analysed in this survey, Kalecik Karası was common in Central Anatolia, Öküzgözü was common in East Anatolia, while Cabernet Sauvignon and Merlot were common in the Aegean region. The significantly higher resveratrol concentration, of $2.28 \mathrm{mg} / \mathrm{L}$, in the wine produced from the Çalkarası black grape was thought to be due to its native variety in the Denizli region. Besides, the Kalecik Karası grape is native to Ankara while the Öküzgözü grape is native to Elazığ. Hence the resveratrol concentrations of the wines that are produce from these two varieties are also higher than the concentrations in the wines from the same varieties grown in both Denizli regions. A value of $0.298 \mathrm{mg} / \mathrm{L}$ was 
obtained in the wine made from the Kalecik Karası variety grown in Denizli, which was lower than the concentration of resveratrol in the wine from the same variety grown in Ankara (0.372 mg/L). Similarly, the value of $1.49 \mathrm{mg} / \mathrm{L}$ in the wine from the Öküzgözü variety grown in Denizli was lower than the concentration of resveratrol in the wine from the same variety grown in Elazı $\mathrm{g}(2.59 \mathrm{mg} / \mathrm{L})(\mathrm{p}=0.05)$. The resveratrol concentration of wine produced from a Boğazkere black grape, which is a native variety of East Anatolia, was $0.601 \mathrm{mg} / \mathrm{L}$ and $0.495 \mathrm{mg} / \mathrm{L}$ for the samples obtained from the Elazığ and Denizli regions respectively (Fig. 1). In this study, the resveratrol concentrations obtained from 21 wine samples were compared statistically using the Tukey method (Table 2).

The resveratrol concentrations of the Cabernet Sauvignon and Merlot grapes were concentrated in two statistical groups according to the Tukey analyses (group a and b), as shown in Table 2 . Since these two varieties are grown widely in many regions of Turkey, Cabernet Sauvignon from five regions and Merlot from four regions were compared with respect to resveratrol concentrations.

In this study, meteorological data such as total effective temperature, sunshine duration and rainfall were obtained from the Meteorological Service, and the vegetation time was obtained from the producers; these are shown in Tables 5 and 6, respectively. The resveratrol concentrations of the wines detected by the HPLC method were evaluated separately for two varieties using Tukey's statistical method (Tables 3 and 4). Lastly, the effects of all these parameters on the resveratrol concentrations of wines are discussed.

According to the results, the resveratrol concentrations were found to be in the same group for Cabernet Sauvignon in the Denizli, İzmir and Çanakkale 1 regions; the Çanakkale 2 region was found to be in the other group, while the Tekirdag region was between these two groups. Wines produced from the same kind of grapes varied in terms of sunshine duration, rainfall and total effective temperature when evaluated according to the different regions (Table 5 and Fig. 2).

Since the shortest vegetation time (97 days) was associated with the grapes grown in Denizli, the total effective temperature and sunshine duration were lower than expected. This is due to the fact that these two parameters are important for the ripeness of grapes, and thus resveratrol synthesis is dependent on the vegetation time of vineyards. Accordingly, limited time for growth decreases the effect of these parameters on the synthesis of resveratrol in grapes compared to the ones that have had sufficient time to reach ripeness (Jeandet et al., 1995). It was noteworthy that the resveratrol concentration of wines produced from Cabernet Sauvignon grapes, which have the longest vegetation time in Tekirdağ (Table 5), was $0.44 \mathrm{mg} / \mathrm{L}$. In this region, the length of the vegetation time also resulted in the highest total effective temperature. Moreover, the higher concentration of resveratrol obtained in the same area, despite the lower sunshine duration (1 170 hours) than in the Çanakkale 1 region, suggests that the total effective temperature is a more important parameter than sunshine duration. Referring to Table 5, the lowest resveratrol concentration observed in grapes grown in the area with the least amount of rainfall, namely İzmir $\left(866 \mathrm{~kg} / \mathrm{m}^{2}\right)$, contradicted the knowledge about abiotic stress. Drought is an abiotic stressor for grapes, so this stress might be a reason for the low resveratrol concentration. Whereas low rainfall increases the resveratrol concentration due to drought stress on the plant, high rainfall activates the formation of pathogens on the plant. Jeandet et al. (1995) found that the factor that affects the resveratrol concentration in wines was the balance with the concentration of resveratrol synthesised in grapes and the degradation of resveratrol by pathogens such as Botrytis cinerea. Thus, high rainfall might increase fungal diseases, especially Botrytis cinerea infection, and resveratrol concentration will decrease due to degradation by these pathogens. However, it should be emphasised that data about the cultural processes applied to the vineyard should be obtained in order to represent the reasons for correlation with the resveratrol concentrations and parameters of different areas.

When another variety of grape, Merlot, was examined in terms of different vegetation time and meteorological conditions, it was found that there were no statistical differences between the resveratrol concentrations of the wines $(0.403$ and $0.477 \mathrm{mg} / \mathrm{L})$ produced from Merlot grapes from the Denizli and Tekirdağ regions (Table 4 and Fig. 3). However, the resveratrol concentrations of the wines produced from Merlot grapes from the Çanakkale 1 and Çanakkale 2 regions were found to be statistically different, with values of 1.21 and $1.52 \mathrm{mg} / \mathrm{L}$ respectively (Table 4$)$. The results in relation to the resveratrol concentrations of wines showed that the grapes grown in the Denizli region, which has the shortest vegetation time and sunshine duration, had the lowest resveratrol concentration $(0.4 \mathrm{mg} / \mathrm{L})$ (Table 6).

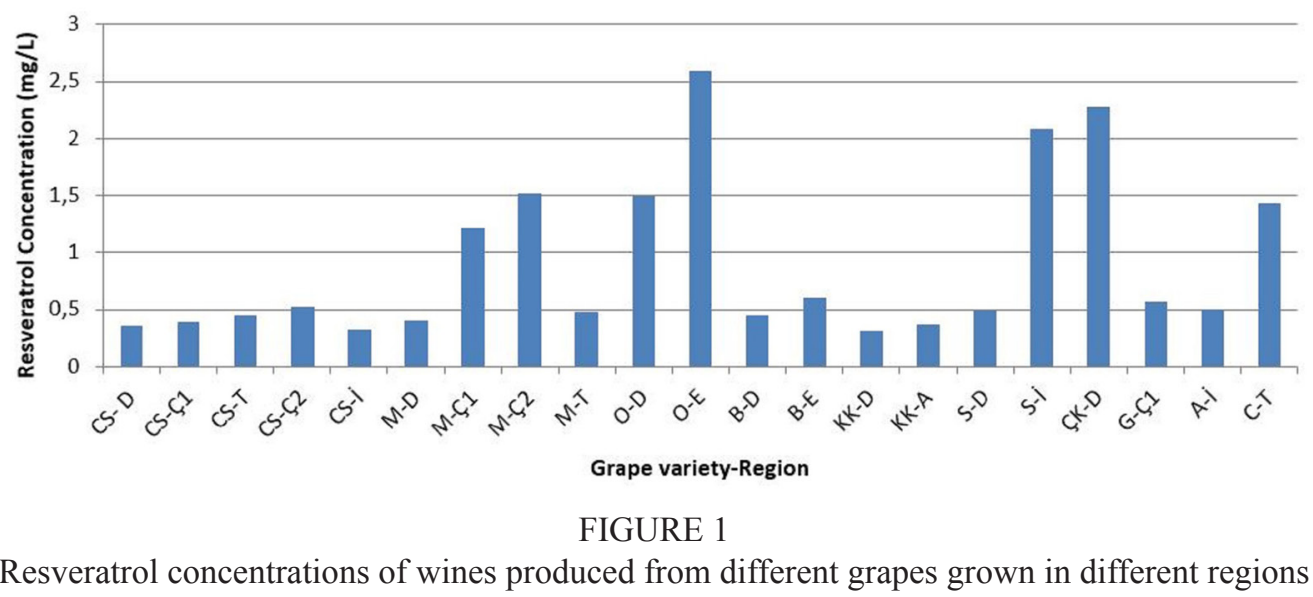


TABLE 2

Statistical evaluation of the wines according to grape varieties and regions.

\begin{tabular}{llllll}
\hline $\begin{array}{l}\text { Grape } \\
\text { varieties }\end{array}$ & Region & $\begin{array}{l}\text { Resveratrol } \\
\text { conc. }(\mathbf{m g} / \mathbf{L})\end{array}$ & $\begin{array}{l}\text { Grape } \\
\text { varieties }\end{array}$ & Region & $\begin{array}{l}\text { Resveratrol } \\
\text { conc. }(\mathbf{m g} / \mathbf{L})\end{array}$ \\
\hline Cabernet Sauvignon & Denizli & $0.3513 \mathrm{a}$ & Cabernet Sauvignon & Tekirdağ & $0.4437 \mathrm{a}$ \\
Öküzgözü & Denizli & $1.4933 \mathrm{~b}$ & Grenache & Çanakkale 1 & $0.5687 \mathrm{a}$ \\
Boğazkere & Denizli & $0.4950 \mathrm{a}$ & Cabernet Sauvignon & Çanakkale 2 & $0.53 \mathrm{a}$ \\
Kalecik Karası & Denizli & $0.2980 \mathrm{a}$ & Cabernet Sauvignon & İzmir & $0.3197 \mathrm{a}$ \\
Syrah & Denizli & $0.45 \mathrm{a}$ & Alicante & İzmir & $0.4967 \mathrm{a}$ \\
Merlot & Denizli & $0.4033 \mathrm{a}$ & Cinsault & Tekirdă̆ & $1.4233 \mathrm{~b}$ \\
Çalkarası & Denizli & $2.2783 \mathrm{~cd}$ & Syrah & İzmir & $2.0830 \mathrm{c}$ \\
Merlot & Çanakkale 1 & $1.2137 \mathrm{~b}$ & Boğazkere & Elazı̆̆ & $0.6013 \mathrm{a}$ \\
Merlot & Çanakkale 2 & $1.5157 \mathrm{~b}$ & Kalecik karası & Ankara & $0.3717 \mathrm{a}$ \\
Cabernet Sauvignon & Çanakkale 1 & $0.3857 \mathrm{a}$ & Öküzgözü & Elazı̆̆ & $2.5943 \mathrm{~d}$ \\
& & & Merlot & Tekirdağ & $0.4773 \mathrm{a}$ \\
\hline
\end{tabular}

TABLE 3

Statistical evaluation of the resveratrol concentration of Cabernet Sauvignon according to regions.

\begin{tabular}{llc}
\hline Region & \multicolumn{2}{c}{ Resveratrol concentration (mg/L) } \\
\hline \multirow{2}{*}{ Denizli } & 0.378 & $0.3511 \mathrm{a}$ \\
& 0.420 & $0.3859 \mathrm{a}$ \\
Çanakkale 1 & 0.410 & $0.4434 \mathrm{ab}$ \\
& 0.405 & \\
Tekirdağ & 0.342 & $0.5300 \mathrm{~b}$ \\
& 0.386 & 0.511 \\
Çanakkale 2 & 0.434 & $0.3197 \mathrm{a}$ \\
\end{tabular}

Tukey HSD, subset for alpha $=0.05$

TABLE 4

The statistical evaluation of the resveratrol concentration of Merlot according to regions.

\begin{tabular}{lcc}
\hline Region & \multicolumn{2}{c}{ Resveratrol concentration (mg/L) } \\
\hline \multirow{2}{*}{ Denizli } & 0.521 & $0.4031 \mathrm{a}$ \\
& 0.340 & 0.349 \\
& 1.197 & $1.2140 \mathrm{~b}$ \\
Çanakkale 1 & 1.234 & \\
& 1.210 & $1.5159 \mathrm{c}$ \\
Çanakkale 2 & 1.544 & \\
& 1.581 & \\
Tekirdağ & 1.422 & $0.4771 \mathrm{a}$ \\
\hline
\end{tabular}

Tukey HSD, subset for alpha $(\mathrm{p}=0.05)$ 

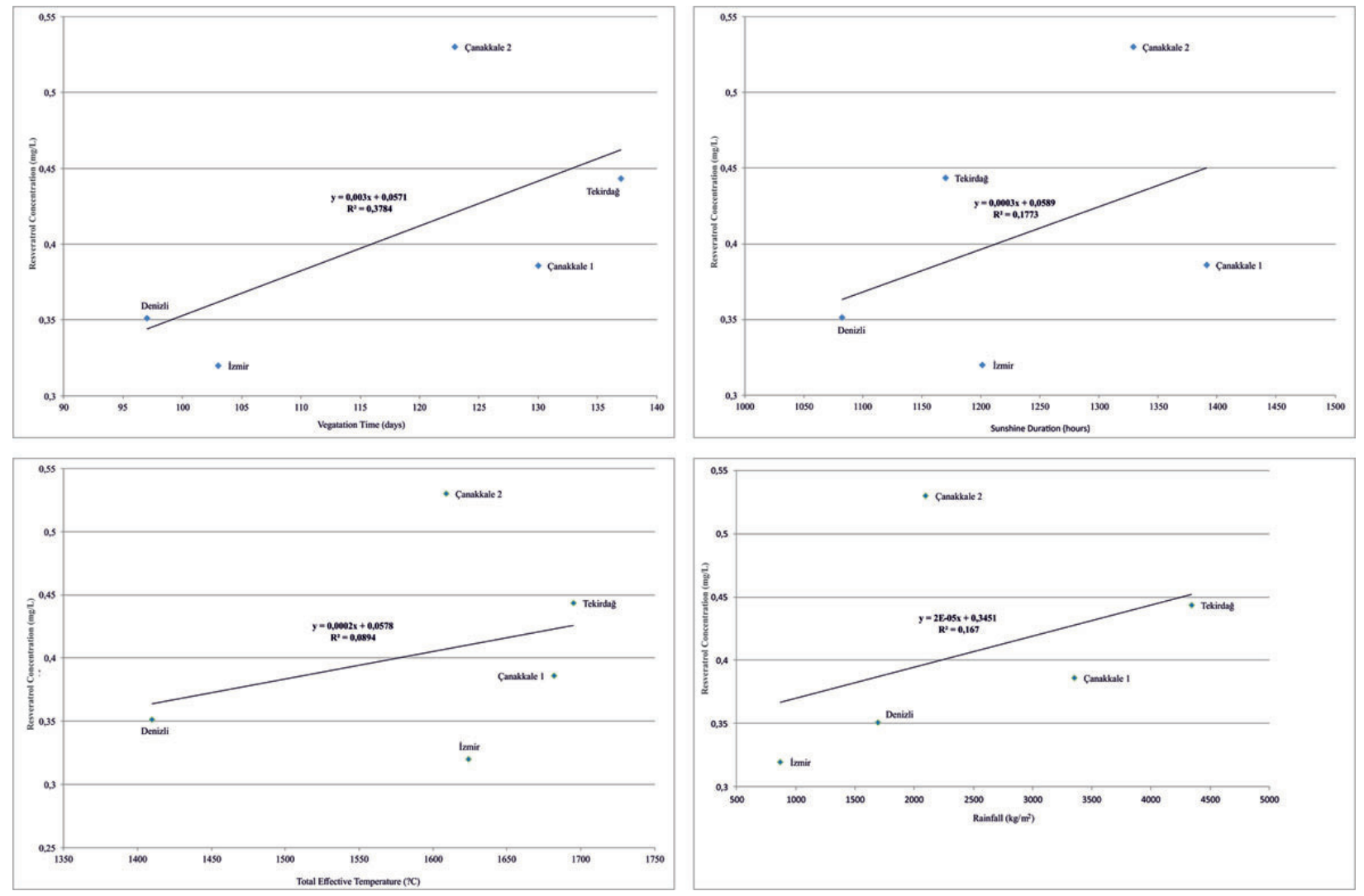

FIGURE 2

Resveratrol concentrations of wines produced from Cabernet Sauvignon according to vegetation time and climatic conditions.
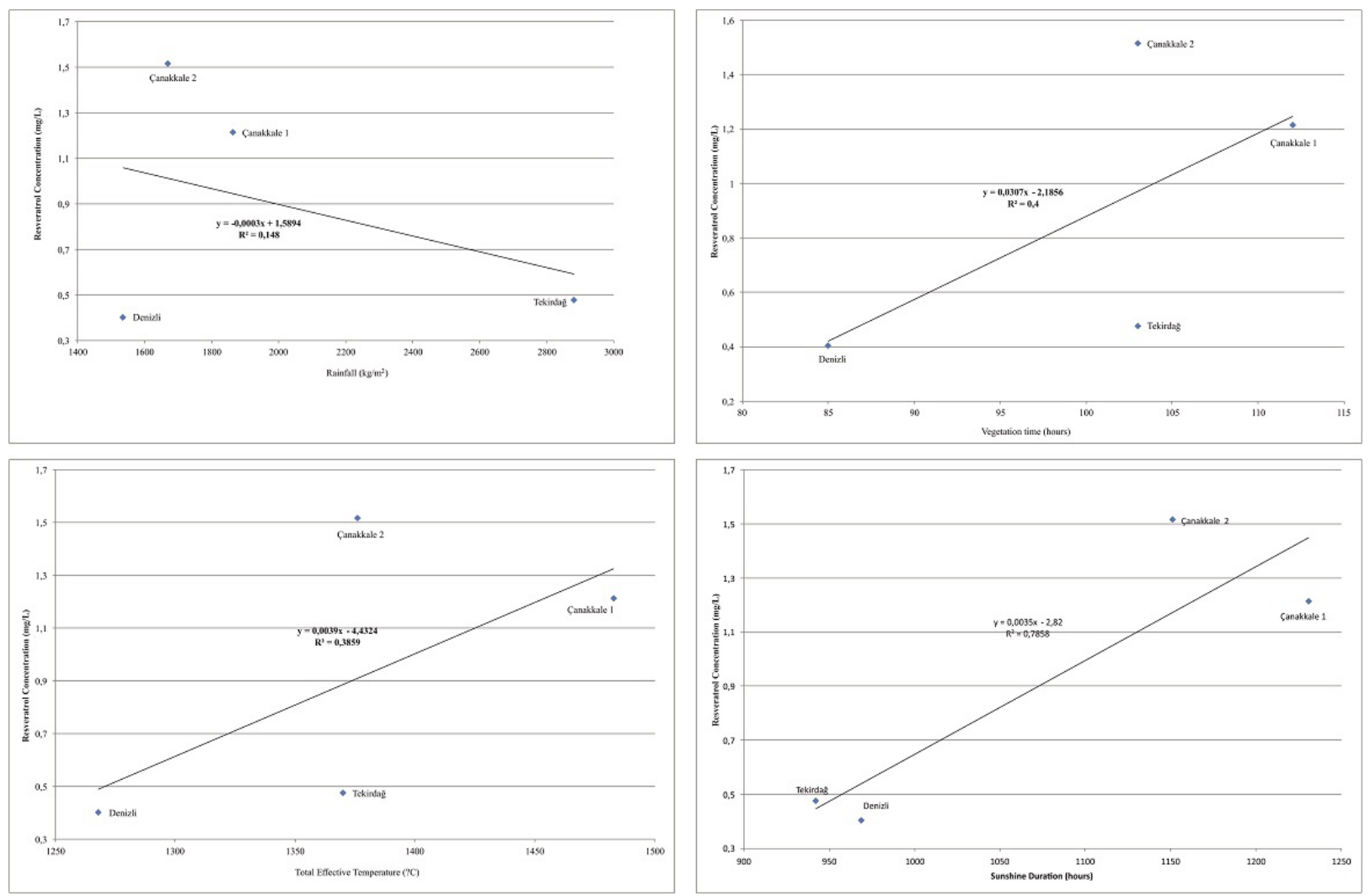

FIGURE 3

Resveratrol concentrations of wines made from Merlot in terms of vegetation time and climatic conditions. 
TABLE 5

Resveratrol concentrations of the Cabernet Sauvignon according to different parameters.

\begin{tabular}{llllll}
\hline & $\begin{array}{l}\text { Resveratrol } \\
\text { concentration } \\
(\mathbf{m g} / \mathbf{L})\end{array}$ & $\begin{array}{l}\text { Vegetation time } \\
\mathbf{( V T ;} \text { days })\end{array}$ & $\begin{array}{l}\text { Total effective } \\
\text { temperature } \\
\left.\mathbf{( T E T ;}{ }^{\circ} \mathbf{C}\right)\end{array}$ & $\begin{array}{l}\text { Sunshine duration } \\
\text { (SD; } \mathbf{h})\end{array}$ & $\begin{array}{l}\text { Rainfall } \\
\left(\mathbf{R} ; \mathbf{~ k g} / \mathbf{m}^{2}\right)\end{array}$ \\
\hline Region & 0.351 & 97 & 1410 & 1082 & 1692 \\
Çanakkale 1 & 0.386 & 130 & 1682 & 1391 & 3352 \\
Tekirdağ & 0.443 & 137 & 1695 & 1170 & 4342 \\
Çanakkale 2 & 0.530 & 123 & 1609 & 1329 & 2098 \\
İzmir & 0.3197 & 103 & 1624 & 1201 & 866 \\
\hline
\end{tabular}

TABLE 6

Resveratrol concentrations of Merlot according to different parameters

\begin{tabular}{llllll}
\hline & $\begin{array}{l}\text { Resveratrol } \\
\text { concentration } \\
\text { (mg/L) }\end{array}$ & $\begin{array}{l}\text { Vegetation time } \\
\text { (VT; days) }\end{array}$ & $\begin{array}{l}\text { Total effective } \\
\text { temperature } \\
\left.\text { (TET; }{ }^{\circ} \mathbf{C}\right)\end{array}$ & $\begin{array}{l}\text { Sunshine duration } \\
\text { (SD; } \mathbf{h})\end{array}$ & $\begin{array}{l}\text { Rainfall } \\
\left(\mathbf{R} ; \mathbf{~ k g} / \mathbf{m}^{2}\right)\end{array}$ \\
\hline Degion & 0.403 & 85 & 1268 & 969 & 1534 \\
Çanakkali & 1.21 & 112 & 1483 & 1231 & 1863 \\
Çanakkale 2 & 1.52 & 103 & 1376 & 1151 & 1670 \\
Tekirdağ & 0.477 & 103 & 1370 & 942 & 2880 \\
\hline
\end{tabular}

The vegetation time of Merlot grapes that were grown in Denizli was significantly short compared to all the others (85 days). Thus, the total effective temperature and sunshine duration were affected negatively (Table 6). In the Çanakkale 1 and 2 regions, the values of all three parameters (VT, TET and SD) were similar, thus high concentrations of resveratrol could be obtained from Merlot grapes that were grown in these regions, with values of 1.21 and $1.52 \mathrm{mg} / \mathrm{L}$ respectively. The reason for the higher resveratrol concentration in Çanakkale $2(1.52 \mathrm{mg} / \mathrm{L})$ can be explained by the rainfall parameter. In this region, the rainfall was $1670 \mathrm{~kg} / \mathrm{m}^{2}$, whereas it was $1863 \mathrm{~kg} / \mathrm{m}^{2}$ in Çanakkale 1 (Table 6). Water stress is an abiotic stress for grapes in ripeness, therefore resveratrol synthesis is expected to be higher than in drought conditions (Adigüzel et al., 2010).

The resveratrol concentrations also showed differences in relation to grape varieties. The results from the wines obtained from Merlot that were grown in Çanakkale 1 and 2 regions were significantly higher than the other concentrations from the same variety (Table 4) and the concentrations obtained from Cabernet Sauvignon wines (Table 3), with 1.21 and $1.52 \mathrm{mg} / \mathrm{L}$ respectively. It is known that an important ampelographic characteristic of Merlot grapes is the sensitivity to winter frost, and these regions are expected to experience more frost than all the other regions that were examined in this study (Çelik, 2006).

\section{CONCLUSIONS}

The results show that the differences in the resveratrol concentrations in wines obtained from different regions depend on grape variety, climatic conditions of the region, and vegetation time. In this study, resveratrol concentration in wines made from different grapes grown in the Aegean,
Marmara, Central Anatolia, Thrace and East Anatolia regions were determined, and the relationship of these values to the vegetation time applied to vineyards and climatic conditions was presented. The highest resveratrol concentration was found in wine produced from the Öküzgözü grape, unique to the East Anatolian region. The effects of different geographical conditions and vegetation time on resveratrol concentration were studied for the Cabernet Sauvignon and Merlot varieties, since they are grown more widely in Turkey, and statistically a greater correlation was found between these two varieties. The results show that the resveratrol concentration in Merlot wines was higher than that in Cabernet Sauvignon, without considering any other parameters. It was observed that there was a direct correlation between the resveratrol concentrations and the parameters of vegetation time, total effective temperature and sunshine duration, while the relationship between the resveratrol concentration and rainfall was found to be indirect. In this study, vegetation time and climatic conditions, which effect the resveratrol concentrations of grapes, were analysed and discussed. Future studies could focus on investigating the correlations between the effective parameters of resveratrol concentration and cultural processes such as pesticide programme, agricultural irrigation and fertilisation.

\section{LITERATURE CITED}

Adıgüzel, B., Çetinkaya, N. \& Yücel. U.C., 2010. Sauvignon ve Merlot Şaraplarının Resveratrol Düzeyleri ve Ekolojik Koşulların Etkileri. Gıda 35, 27-32.

Adıgüzel, B., Yücel, U. \& Çetinkaya, N., 2009. Farklı Bölgelerin Üzümlerinden Üretilen Türk Şaraplarında Resveratrol Düzeyleri. Gıda 34 381-386. 
Anl1, E., Vural, N., Demiray, S. \& Özkan, M., 2006. Trans-resveratrol and other phenolic compounds in Turkish red wines with HPLC. J. Wine Res. $17,117-125$

Bravo, M.N., Silva, S., Coelho, A.V., Boas, L.V. \& Bronze, M.R., 2006. Analysis of phenolic compounds in Muscatel wines produced in Portugal. Anal. Chim. Acta 56, 84-92.

Cottart, C.-H., Nivet-Antoine, V., Laguillier-Morizot, C. \& Beaudeux J.-L., 2010. Resveratrol bioavailability and toxicity in humans. Molecular Nut. Food Res. 54, 7-16.

Cui, J., Juhasz, B., Tosaki, A., Maulik, N. \& Das, D.K., 2002. Cardioprotection with grapes. J. Cardiovasc. Pharm. 40, 762-769.

Çelik, H. 2006. Grape cultivar catalog. Univ. Ankara, Dep. Hort., Sunfidan A.Ș. Mesleki Kitaplar Serisi 3, 132.

Denzer, H. 1991. Resistenz von rebsorten gegen Plasmopara viticola. Justus- Liebig Universität Giessen, Germany, Inaugural-Dissertation, 133.

Gerogiannaki-Christopoulou, M., Athanasopoulos, P., Kyriakidis, N., Gerogiannaki, I.A. \& Spanos, M., 2006. Trans-resveratrol in wines from the major Greek red and white grape varieties. Food Control 17, 700-706.

Gürbüz, O., Göçmen, D., Dağdelen, F., Gürsoy, M., Aydın, S., Şahin, İ., Büyükuysal, L. \& Usta, M., 2007. Determination of flavan-3-ols and transresveratrol in grapes and wine using HPLC with fluorescence detection. Food Chem. 100, 518-525.

İkizler, M., Dernek, S., Erkasap, N., Kaygısız, Z., Sevin, B. \& Kural, T., 2003. İzole rat kalplerine uygulanan reperfüzyon hasarında resveratrolün hemodinamik etkileri. Türk Göğüs Kalp Damar Cerrahi Dergisi 11, 91-95.

Jeandet, P., Bessis, R., Sbaghi, M., Meunier, P. \& Trollat, P., 1995. Resveratrol content of wines of different ages: Relationship with fungal disease pressure in the vineyard. Am. J. Enol. Vitic. 46, 1-3.
Montsko, G., Ohmacht, R. \& Mark, L., 2010. Trans-resveratrol and transpiceid content of Hungarian wines. Chromatographia Suppl. 71, 121-124.

Olson, O.R., Naugle, J.E., Zhang, X., Bomser, J.A. \& Meszaros, J.G. 2005. Inhibition of cardiac fibroblast proliferation and myofibroblast differentiation by resveratrol. Am. J. Phys. and Heart Circul. Phys. 3, 288 290

Paulo, L., Domingues, F., Queiroz, J. \& Gallardo, E., 2011. Development and validation of an analytical method for the determination of trans- and cis-resveratrol in wine: Analysis of its contents in 186 Portuguese red wines. J. Agric. Food Chem. 59, 2157-2168.

Rastija V., Srečnik G. \& Šaric M.M., 2009. Polyphenolic composition of Croatian wines with different geographical origins. Food Chem. 115, 54-60.

Schaffer, S., Asseburg, H., Kuntz, S., Muller, W. \& Eckert, G., 2012 Effects of polyphenols on brain ageing and Alzheimer's disease: Focus on mitochondria. Mol. Neurobiol. 46, 161-178.

Singh, C.K., Ndiaye, M.A. \& Ahmad, N., 2015. Resveratrol and cancer Challenges for clinical translation. BBA - Molec. Bas. Disease 6, 11781185 .

Stervbo, U., Vang, O. \& Bonnesen, C., 2007. A review of the content of the putative chemopreventive phytoalexin resveratrol in red wine. Food Chem. 101, 459-457.

Threlfall, R.T., Morris, J.R. \& Mauromoustakos, A., 1999. Effect of variety, ultraviolet light exposure, and enological methods on the trans-resveratrol level of wine. Am. J. Enol. Vitic. 50, 57-64.

Vincenzi, S., Tomasi, D., Gaiotti, F., Lovat, L., Giacosa, S., Torchio, F. Segade, S.R. \& Rolle, L., 2013. Comparative study of the resveratrol content of twenty-one Italian red grape varieties. S. Afr. J. Enol. Vitic. 34, 30-35.

Zielińska, P.M., Ignatowicz, E., Krajka-Kuźniak, V. \& Baer-Dubowska, W., 2015. Effect of tannic acid, resveratrol and its derivatives, on oxidative damage and apoptosis in human neutrophils. Food and Chem. Toxic. 84, 37-46. 